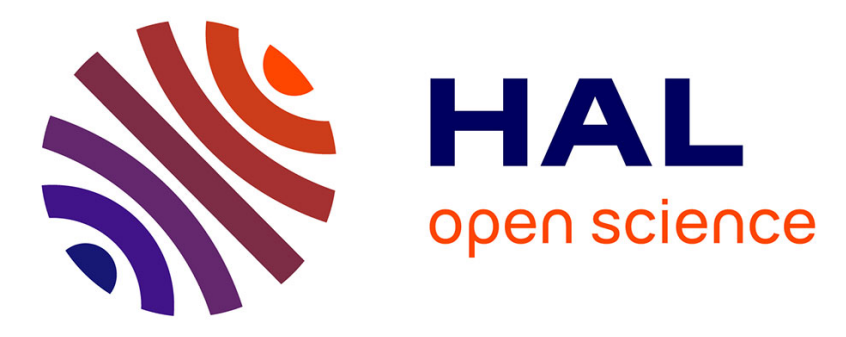

\title{
Mercury in wintering seabirds, an aggravating factor to winter wrecks?
}

Jérôme Fort, Thomas Lacoue-Labarthe, Hanh Linh Nguyen, Amélie Boué, Jérôme Spitz, Paco Bustamante

\section{- To cite this version:}

Jérôme Fort, Thomas Lacoue-Labarthe, Hanh Linh Nguyen, Amélie Boué, Jérôme Spitz, et al.. Mercury in wintering seabirds, an aggravating factor to winter wrecks?. Science of the Total Environment, 2015, 527-528, pp.448-454. 10.1016/j.scitotenv.2015.05.018 . hal-01186129

\section{HAL Id: hal-01186129 \\ https://hal.science/hal-01186129}

Submitted on 24 Aug 2015

HAL is a multi-disciplinary open access archive for the deposit and dissemination of scientific research documents, whether they are published or not. The documents may come from teaching and research institutions in France or abroad, or from public or private research centers.
L'archive ouverte pluridisciplinaire HAL, est destinée au dépôt et à la diffusion de documents scientifiques de niveau recherche, publiés ou non, émanant des établissements d'enseignement et de recherche français ou étrangers, des laboratoires publics ou privés. 
Mercury in wintering seabirds, an aggravating factor to winter wrecks?

Fort Jérôme ${ }^{1, *}$, Lacoue-Labarthe Thomas ${ }^{1}$, Nguyen Hanh Linh $^{1,2}$, Boué Amélie ${ }^{3}$, Spitz Jérôme ${ }^{4}$, Bustamante Paco ${ }^{1}$

${ }^{1}$ Littoral, Environnement et Sociétés, UMRi 7266 CNRS-Université La Rochelle, 2 rue Olympe de Gouges, 17000 La Rochelle, France

${ }^{2}$ University of Science and Technology of Hanoi, 18 Hoang Quoc Viet, CauGiay, Hanoi, Vietnam

${ }^{3}$ LPO (Ligue pour la Protection des Oiseaux), Fonderies Royales, 8 rue du Dr Pujos, 17305

Rochefort, France

${ }^{4}$ Observatoire PELAGIS, UMS 3462 CNRS-Université La Rochelle, La Rochelle, France

Email addresses: Fort Jérôme: fort.jerome@gmail.com

Lacoue-Labarthe Thomas: thomas.lacoue-labarthe@univ-lr.fr

Nguyen Hanh Linh: linhnguyenhanh@gmail.com

Boué Amélie: amelie.boue@lpo.fr

Spitz Jérôme: jerome.spitz@univ-lr.fr

Bustamante Paco: paco.bustamante@univ-lr.fr

*Corresponding author. Email: fort.jerome@ gmail.com; Tel: +33546458388 
Abstract: Every year, thousands of seabirds cast ashore and are found dead along the coasts of North America and Western Europe. These massive mortality events called 'winter wrecks' have generally been attributed to harsh climatic conditions and prolonged storms which affect bird energy balance and impact their body condition. Nevertheless, additional stress factors, such as contaminant body burden, could potentially cumulate to energy constraints and actively contribute to winter wrecks. However, the role played by these additional factors in seabird massive winter mortality has received little attention to date. In February/March 2014, an unprecedented seabird wreck occurred along the Atlantic French coasts during which $>43.000$ seabirds were found dead. By analyzing mercury $(\mathrm{Hg})$ concentrations in various tissues collected on stranded birds, we tested the hypothesis that $\mathrm{Hg}$ played a significant role in this mortality. More specifically, we aimed to (1) describe $\mathrm{Hg}$ contamination in wintering seabirds found along the French coasts in 2014, and (2) determine if $\mathrm{Hg}$ concentrations measured in some vital organs such as kidney or brain reached toxicity thresholds that could have led to deleterious effects and to an enhanced mortality. We found some of the highest $\mathrm{Hg}$ levels ever reported in Atlantic puffins, common guillemots, razorbills and kittiwakes. Measured concentrations ranged from 0.8 to $3.6 \mu \mathrm{g} . \mathrm{g}^{-1}$ of dry weight in brain, 1.3 to $7.2 \mu \mathrm{g} . \mathrm{g}^{-1}$ in muscle, 2.5 to $13.5 \mu \mathrm{g} . \mathrm{g}^{-1}$ in kidney, 2.9 to $18.6 \mu \mathrm{g} . \mathrm{g}^{-1}$ in blood and from 3.1 to $19.5 \mu \mathrm{g} . \mathrm{g}^{-1}$ in liver. $\mathrm{Hg}$ concentrations in liver and brain were generally below estimated acute toxicity levels. However, kidney concentrations were not different than those measured in the liver, and above levels associated to renal sub-lethal effects, suggesting a potential $\mathrm{Hg}$ poisoning. We concluded that althoughHg was not directly responsible for the high observed mortality, it has been a major aggravating stress factor for emaciated birds already on the edge. Importantly, this study also demonstrated that total blood, which can be non-lethallycollected in seabirds, can be used as a predictor of $\mathrm{Hg}$ contamination in other tissues.

Keywords: Bay of Biscay, Massive mortality, Mercury, North Atlantic, Seabirds, Winter wreck 


\section{Introduction}

Every year, thousands of seabirds cast ashore and are found dead along the coasts of North America and Western Europe (e.g. Piatt \& Pelt 1997, Gaston 2004, Harris\&Wanless 2013). These massive mortality events called 'winter wrecks' have generally been attributed to harsh climatic conditions and prolonged storms which affect birds foraging efficiency and enhance thermoregulatory costs, thereby affecting their energy balance, impacting their body conditions and ultimately increasing their mortality (Fort et al. 2009). Hence, alcidswhich have little energy reserves and cannot survive longer than 3-4 days without foraging (Gaston et al., 1983; Gaston and Jones, 1998) are the first affected by starvation and the most exposed to harsh conditions. However, other additional factors could cumulate to bird energy constraints and actively contribute to winter wrecks. For instance parasite load or diseases could affect individual immune system and therefore enhance their sensitivity to energy constraints (Bulté et al. 2012). Contaminant body burden could also be a factor playing a significant role in these massive mortality events. Indeed, through an acute toxicity (see Wolfe et al. 1998), by affecting bird physiology and behavior (Tan et al. 2009) or by increasing energy requirements to sustain detoxification mechanisms (Lucia et al. 2012), contaminants could directly or indirectly impact their survival. However, very little is known about the role played by these additional factors in seabird winter wrecks (Debacker et al. 2000, 2001a). A better understanding of cumulative effects would benefit to the conservation of these vulnerable species during a critical period of their life-cycle.

Among contaminants present in the marine environment which could affect seabird mortality, the study of mercury $(\mathrm{Hg})$ is of particular interest. $\mathrm{Hg}$, and most particularly methyl- $\mathrm{Hg}$, is indeed a powerful neurotoxicant in marine top-predators (e.g. Wolfe et al. 1998,Dietz et al. 2013) which can, through brain lesions or endocrine disruptive effects, affect seabird behavior 
and ultimately shape their survival (Wolfe et al. 1998, Tartu et al. 2013,Goutte et al. 2014a,b). High $\mathrm{Hg}$ concentrations in other tissues (e.g. kidney or liver) could as well cause acute poisoning and impact seabird survival (Wolfe et al. 1998). Elevated concentrations of $\mathrm{Hg}$ were previously found in stranded wintering seabirds from the Northern Hemisphere (Debacker et al. 1997, Joiris et al. 1997). Hence, some authors suggested that Hg could be an additional stress factor that could partly result in the death of birds (Debacker et al. 2000).

In February and March 2014, an unprecedented seabird wreck occurred along the Atlantic French coasts. Within 6 weeks, a total of $>43.000$ seabirds hadbeen found dead or extremely weakened on beaches (Farque 2014). Atlantic puffins (Fraterculaarctica) and common guillemots (Uriaaalge), two species of the alcid family, were the most affected, representing $66 \%$ and $27 \%$ of stranded birds, respectively (Farque 2014). Almost all birds were emaciated; starvation was designated as the main cause of this massive mortality. However, as dozens of birds of several species were collected on beaches or kept once dead in wildlife centers, they represented a unique opportunity to investigate further $\mathrm{Hg}$ contamination in wintering seabirds, and its potential role in this winter wreck.

By analyzing various tissues collected on stranded birds belonging to four different species, and by comparing $\mathrm{Hg}$ concentrations with those measured in healthy birds, the present study had the following objectives: (1) describe $\mathrm{Hg}$ contamination in stranded seabirds wintering in the Bay of Biscay; (2) test the hypothesis that $\mathrm{Hg}$ concentrations measured in some vital organs such as kidney or brain reached toxicity levels that could have led to deleterious effects and to enhanced bird mortality; (3) determine if whole blood samples could be used as a predictor of $\mathrm{Hg}$ contamination in other seabird tissues. Indeed, while blood can be easily and non-lethally collected in seabirds, measurements of contaminant levels in other tissues are, for ethical issues, more limited. Understanding if/how blood can be used as surrogate to evaluate the contamination of other tissues is therefore essential. 


\section{Materials and Methods}

\subsection{Seabird winter wreck 2014}

For this study, 43 seabird carcasses were collected on the Isle of Rhé $\left(46^{\circ} 1^{\prime} \mathrm{N} 1^{\circ} 2^{\prime} \mathrm{W}\right)$ and on Oléron Island $\left(45.9^{\circ} \mathrm{N} 1.3^{\circ} \mathrm{W}\right)$ during February and March 2014 , and kept frozen at $-20^{\circ} \mathrm{C}$ until analyses. They belonged to four species: Atlantic puffin $(n=15)$, common guillemot ( $\mathrm{n}$ $=13$ ), razorbill (Alcatorda; $\mathrm{n}=7$ ) and black-legged kittiwake (Rissatridactyla; $\mathrm{n}=8$ ). Part of these birds was collected freshly dead on beaches $(n=15)$ while another part $(n=28)$ was found alive by walkers and brought to a Wildlife Care Center where they died within 24 hours. We assumed that these few hours spent at the Care Center did not affect $\mathrm{Hg}$ concentrations in bird tissues. During dissections, sex was defined by visual inspection of gonads and age of all individuals was determined following plumage patterns or morphological criteria (Pyle 2009). In the present study, only adult birds were analysed. The entire liver, kidney and brain were collected as well as some pectoral muscle and whole blood (hereafter 'blood') samples (from the cardiac clot). All tissues were lyophilized for 48 hours, groundinto powder and homogenized prior to $\mathrm{Hg}$ analyses. Feathers were not analysed in this study since they reflected a different period than internal organs and were therefore not directly comparable. Hg that have accumulated in body tissues are excreted to feathers when birds are moulting and $\mathrm{Hg}$ concentrations in feathers are thus considered to be an indicator of contamination between two moulting sequences rather than a short-term contamination as in other tissues (Furness et al. 1986, Agusa et al. 2005).

Body condition of birds was evaluated through (1) the thickness of their pectoral muscle (Lindström et al. 2000, Moseley et al. 2012) and (2) the calculation of a body condition index (ratio of liver to kidney mass; Wenzel \&Adelung 1996, Debacker et al. 2000). Thickness of 
pectoral muscles was determined using a needle pricked transversally (at a $90^{\circ}$ angle) in the right-side muscle, along the keel of the sternum $(1 \mathrm{~cm}$ from the keel and at mid-length of the keel) (Erbacher 2012).

\subsection{Wintering seabirds in standard, healthy, body condition}

In April 2006, 21 razorbills were found freshly dead on the beach in the southern part of the Bay of Biscay $\left(43^{\circ} 03^{\prime} \mathrm{N}, 01^{\circ} 03^{\prime} \mathrm{W}\right)$. Contrary to razorbills collected in 2014 that were highly emaciated (see results), these birds presented external signs of probable by-catch suggesting they had drowned in fishing gears. We therefore assumed these birds to be in standard, healthy, body conditions at the time of death, and hereafter, they are referred to as 'healthy birds'. Razorbills collected in 2006 were used to compare body conditions as well as the mass of each organ and their Hg contamination levels between stranded (2014) and healthy (2006) razorbills.

\subsection{Mercury analyses}

Total $\mathrm{Hg}$ (hereafter termed $\mathrm{Hg}$ ) concentrations were measured in each tissue at the Littoral Environnement et Sociétés laboratory (LIENSs, La Rochelle, France) using an Advanced MercuryAnalyzer spectrophotometer (Altec AMA 254) as described in Bustamante et al. (2006). Analyses were repeated two to four times for each sample until the relative standard deviation for two samples was $<10 \%$. The mean $\mathrm{Hg}$ concentrations for those two measurements were then considered for statistical analyses. To ensure the accuracy of measurements, a certified reference material was used (Lobster Hepatopancreas Tort-2; NRC, Canada; $\mathrm{Hg}$ concentration of $0.27 \pm 0.06 \mu \mathrm{g} \cdot \mathrm{g}^{-1}$ of dry weight $\left.(\mathrm{dw})\right)$ and measured every 10 samples. The average measured value was $0.28 \pm 0.02 \mu \mathrm{g} \cdot \mathrm{g}^{-1}$ of $\mathrm{dw}(\mathrm{n}=105)$. Additionally, 
blanks were run at the beginning of each sample set. The detection limit of the method was $0.005 \mu \mathrm{g} \cdot \mathrm{g}^{-1}$ of $\mathrm{dw}$.

\subsection{Statistical analyses}

Statistics were computed using R version 3.0.2 (R Development Core Team 2011). Hg data were log-transformed to comply with parametric assumptions of normality and homoscedasticity. Differences in $\mathrm{Hg}$ concentrations between tissues were tested for each species using Repeated Measures ANOVA followed by paired t-test. When sphericity was not met, we used the Greenhouse-Geisser adjustment, consisting in multiplying the numerator and denominator degrees of freedom by $\epsilon$, to calculate adjusted p-values (Greenhouse \&Geisser 1959). Differences in morphometrics, $\mathrm{Hg}$ concentrations and total $\mathrm{Hg}$ content in each organ between stranded (2014) and healthy (2006) razorbills weretested using Student's t tests. Relationships of $\mathrm{Hg}$ concentrationsbetween blood and other tissues were calculated for both emaciated (2014) and healthy (2006) birds. ANCOVA were used to test for a potential effect of bird state on the intercept and the slope of the regression line when blood was compared to other tissues. If bird state had no effect, data from all species and both bird states were pooled to evaluate how $\mathrm{Hg}$ concentrations in these tissues were related to $\mathrm{Hg}$ in blood. If bird state affected the relationship between blood and $\mathrm{Hg}$ concentrations in other tissues (intercept or slope),concentrations measured in emaciated and healthy birds were then treated separately. All data are presented as mean $\pm \mathrm{SD}$. All provided $\mathrm{Hg}$ concentrations are in $\mu \mathrm{g} \cdot \mathrm{g}^{-1}$ of $\mathrm{dw}$ except otherwise mentioned (a table summarizing measured values in $\mu \mathrm{g} \cdot \mathrm{g}^{-1}$ of wet weight (ww) is presented in the Supplementary Material, Table A.1).

\section{Results}




\subsection{Body condition and $\mathrm{Hg}$ levels in wintering seabirds during the 2014 winter wreck event}

All dissected seabirds from the winter wreck 2014 were extremely emaciated with low body mass and reduced pectoral muscle thickness. As an illustration, wrecked razorbills were $38 \%$ lighter $(420 \pm 40 \mathrm{~g}$ vs $672 \pm 85 \mathrm{~g}$; t-test: $\mathrm{t}=7.5, \mathrm{df}=26, \mathrm{p}<0.001)$, had pectoral muscles $36 \%$ thinner $(13.3 \pm 1.9 \mathrm{~mm}$ vs $20.7 \pm 3.0 \mathrm{~mm}$; $\mathrm{t}$-test: $\mathrm{t}=6.0, \mathrm{df}=26, \mathrm{p}<0.001)$ and had much lower body condition indexes $(1.51 \pm 0.33$ vs $3.19 \pm 0.45 ;$ t-test: $\mathrm{t}=8.9$, df $=25, \mathrm{p}<0.001)$ than those collected in 2006 with healthy body conditions. Kidney and liver masses were also highly reduced in razorbills from 2014 (wet mass, Figure 1). Among birds collected in 2014, alcids had the lowest body condition indexes (razorbills: $1.51 \pm 0.33$, Atlantic puffins: $1.54 \pm$ 0.20, common guillemot: $2.10 \pm 0.48$ ) while black-legged kittiwakes had the highest index $(2.55 \pm 0.77)$.

$\mathrm{Hg}$ concentrations in seabird body tissues followed the pattern: liver $=$ kidney $=$ blood $>$ muscle > brain in razorbills, common guillemots and black-legged kittiwakes, while the pattern was liver $>$ kidney $=$ blood $>$ muscle $>$ brain in Atlantic puffins (see Table 1 ). Measured $\mathrm{Hg}$ concentrations in seabirds from the 2014 wreck ranged from 0.8 to $3.6 \mu \mathrm{g} . \mathrm{g}^{-1} \mathrm{dw}$ in brain, from 1.3 to $7.2 \mu \mathrm{g} . \mathrm{g}^{-1} \mathrm{dw}$ in muscle, from 2.5 to $13.5 \mu \mathrm{g} . \mathrm{g}^{-1} \mathrm{dw}$ in kidney, from 2.9 to 18.6 $\mu \mathrm{g} \cdot \mathrm{g}^{-1} \mathrm{dw}$ in blood and from 3.1 to $19.5 \mu \mathrm{g} \cdot \mathrm{g}^{-1} \mathrm{dw}$ in liver. Overall, Hg concentrations were higher in razorbills and kittiwakes than in Atlantic puffins and common guillemots (see Table 1)

ANCOVA showed that bird state affected either the slope or the intercept of the regression lines when blood was related to liver $(\mathrm{p}=0.458$ and $\mathrm{p}<0.001$, respectively), kidney $(\mathrm{p}=$ 0.118 and $p<0.01$, respectively) and brain $(p=0.171$ and $p<0.001$, respectively). For these three tissues, concentrations measured in emaciated and healthy birds were therefore treated 
separately. However, bird state did not affect the slope or the intercept of the regression lines when blood was related to muscle ( $\mathrm{p}=0.552$ and $\mathrm{p}=0.918$, respectively). Data from all species and both bird states were therefore pooled to evaluate how $\mathrm{Hg}$ concentrations in muscle were related to $\mathrm{Hg}$ in blood.

In both emaciated and healthy bird groups, $\mathrm{Hg}$ concentrations measured in blood were positively and linearly correlated to $\mathrm{Hg}$ concentrations in all other tissues (Figure 2) following equations presented in Table 2.

\subsection{Comparison of razorbills collected in 2006 and 2014}

To investigate further the potential role of $\mathrm{Hg}$ in seabird massive mortality, we compared data obtained on razorbills assumed to be in healthy body condition (collected in 2006) and on razorbills from the 2014 winter wreck. As mentioned above, weighed internal tissues showed a lower mass in birds collected in 2014 (71\% lower in liver: $9.4 \pm 2.7 \mathrm{~g} v s 32.1 \pm 5.3 \mathrm{~g}$, t-test: $\mathrm{t}=10.8, \mathrm{df}=25, \mathrm{p}<0.001 ; 40 \%$ lower in kidney: $6.1 \pm 0.5 \mathrm{~g} v s 10.1 \pm 0.9 \mathrm{~g}, \mathrm{t}=10.7, \mathrm{df}=$ $25, \mathrm{p}<0.001)$, except in brain for which the measured mass was similar between the two groups $(3.8 \pm 0.2 \mathrm{~g} v s 3.9 \pm 0.3 \mathrm{~g}, \mathrm{t}=0.22, \mathrm{df}=25, \mathrm{p}=0.833$; Figure 1$)$. Concurrently to this lower mass, all internal tissues (but brain; $p=0.712$ ) of stranded birds collected in 2014 showed higher $\mathrm{Hg}$ concentrations (Table 1, Figure 1; all $\mathrm{p}<0.01$ ). However, and despite these higher $\mathrm{Hg}$ concentrations, the total $\mathrm{Hg}$ content (expressed in $\mathrm{mg}$ of $\mathrm{Hg}$ ) was lower in livers of birds collected during the winter wreck $2014(\mathrm{t}=3.19, \mathrm{df}=15, \mathrm{p}=0.011)$, and similar between the two groups in kidney and brain (Table 1 , Figure $1 ; \mathrm{t}=1.67, \mathrm{df}=25, \mathrm{p}=$ 0.063 andt $=0.26, \mathrm{df}=25, \mathrm{p}=0.799$, respectively)

\section{Discussion}




\subsection{Hg as an aggravating factor of seabird winter mortality}

Seabird massive winter mortality events are frequently responsible for the death of thousands to tens of thousands individuals all around the Northern Hemisphere; 'unprecedented' being more and more used to qualify these events (e.g. Harris \&Wanless 2013, Farque 2014, The Seabird Group 2015). In most of the cases, starvation is considered as the main cause for this mortality. However, the potential role played by additional factors has been barely investigated (e.g. Piatt \& Van Pelt 1997, Debacker et al. 2001a). Here, we analysed for the first time $\mathrm{Hg}$ concentrations in several species washed up on shore during a massive winter wreck, and examined five different internal tissues in order to investigate the potential role played by $\mathrm{Hg}$ in this mortality event.

Our results show that $\mathrm{Hg}$ concentrations found in stranded birds in 2014, whatever the species and the tissue considered, were much higher than concentrations found in healthy birds during the breeding season (for reviews see e.g. Savinov et al. 2003, Espín et al. 2012, Provencher et al. 2014a, Scheuhammer et al. 2015). Different studies previously suggested that $\mathrm{Hg}$ contamination of North Atlantic seabirds could be higher in winter than during the breeding season, due to a shift on consumed prey or to an increased environmental contamination at their wintering grounds (Joiris et al. 1997, Fort et al. 2014). There is, however, very little information about $\mathrm{Hg}$ contamination of seabirds in healthy body conditions during the winter period, limited to a few species, mainly because of the difficulty to assess these individuals at sea. Nevertheless, measurements performed on stranded razorbills during the 2014 winter wreck were again two to four times higher than measurements performed on tissues of wintering healthy razorbills hunted off Newfoundland (Bond et al. 2015) or caught in fishing nets along the Portuguese and Spanish coasts (Ribeiro et al. 2009, Espín et al. 2012) and in 
the Bay of Biscay (this study). Similarly, muscle samples collected on common guillemots wintering off Newfoundland (0.09 $\mu \mathrm{g} . \mathrm{g}^{-1} \mathrm{ww}$; Bond et al. 2015) were about five times less contaminated than samples measured in this study $\left(2.08 \mu \mathrm{g} . \mathrm{g}^{-1} \mathrm{dw}\right.$ corresponding to $0.44 \mu \mathrm{g} . \mathrm{g}^{-}$ $\left.{ }^{1} \mathrm{ww}\right)$. This strongly suggest that stranded seabirds were highly contaminated compared to birds in normal conditions. With the exception of investigations performed after massive oilspills (e.g. Pérez-López et al. 2006, Sanpera et al. 2008), a very few studies, focused on common guillemots only, investigated $\mathrm{Hg}$ concentrations in emaciated birds found dead along the European coasts during winter. They reported similar $\mathrm{Hg}$ concentrations than those found in the present study (Debacker et al. 1997, Joiris et al. 1997).

There is very little information about toxicity levels in wild seabirds. Hepatic $\mathrm{Hg}$ concentrations found in stranded birds, although among the highest measured in these species, are lower than threshold concentrations considered being associated to acute toxic effects in non-marine birds (>5 $\mu \mathrm{g} . \mathrm{g}^{-1}$ of ww; Zillioux et al. 1993, Wolfe et al. 1998, Scheuhammer et al. 2015). Birds present the particularity to have a renal portal system by which blood flows directly from the digestive tract to the kidney prior to entering the hepatic system. Hence, kidney is considered to be more vulnerable to $\mathrm{Hg}$ in birds, this latter damaging the structure of the kidney and impairing the renal function (Wolfe et al. 1998). For instance, average $\mathrm{Hg}$ concentrations of $5 \mu \mathrm{g} \cdot \mathrm{g}^{-1} \mathrm{dw}$ in kidneys of wild Atlantic puffins were found to be associated to sub-lethal kidney lesions suggesting initial toxicological effects (Nicholson et al. 1983, Nicholson \& Osborn 1983). In the present study, we found in all species $\mathrm{Hg}$ concentrations in kidneys > $5 \mu \mathrm{g} \cdot \mathrm{g}^{-1} \mathrm{dw}$. Moreover, all species but Atlantic puffins showed no significant difference of $\mathrm{Hg}$ concentrations in liver and kidney. $\mathrm{Hg}$ levels in wild birds are usually found to be higher in liver than in kidney (Ribeiro et al. 2009, Cipro et al. 2014), and previous studies suggested that such kidney concentrations close to those of liver are an indicator of $\mathrm{Hg}$ poisoning (Wolfe et al. 1998). Finally, a previous experimental study performed on terrestrial 
birds demonstrated that metallic trace elements such as $\mathrm{Hg}$ at similar concentrations than those measured on stranded seabirds could enhance energy constraints and accelerate the cachexia process (Debacker et al. 2001b). All these elements strongly suggest that $\mathrm{Hg}$ has very likely been an aggravating stress factor for birds already on the edge, likely involved in the mortality observed in the four study species.

$\mathrm{Hg}$, and more specifically methyl-Hg, is also known to readily enter the blood-brain barrier, causing brain lesions and central nervous system dysfunctions (Aschner\&Aschner 1990, Rutkiewicz et al. 2011, Dietz et al. 2013). This link between blood and brain is confirmed by the significant and strong correlation between $\mathrm{Hg}$ concentrations in blood and $\mathrm{Hg}$ concentrations in brain observed in both stranded and healthy birds (Figure2D, Table 2). In stranded birds, the loss of liver and kidney masses caused by starvation led to lower mercury loads in these organs (close to significance in kidney) and concomitant higher $\mathrm{Hg}$ concentrations in blood. This strongly suggests a release and remobilization of $\mathrm{Hg}$ in their blood stream.However, this enhanced circulating $\mathrm{Hg}$ has not been transferred to the brain. Hence, and contrary to our prediction, our resultsshow that despite a higher contamination of stranded birds compared to healthy ones, $\mathrm{Hg}$ levels did not differ in brains of these two groups, limiting additional neurotoxic effects in the former one. Interestingly, these results suggest that the increase of $\mathrm{Hg}$ concentrations in blood of emaciated birds has been too fast to affect their brain levels before bird death.

\subsection{The use of wholeblood samples as surrogate to evaluate seabird contamination}

Blood is, with feathers, the most commonly collected tissue in seabirds (including for the study species) as it can be non-lethallysampled. Blood reflects the short-term $\mathrm{Hg}$ contamination of individuals and therefore provides information for the sampling period, 
usually the breeding season in seabirds (e.g. Goodale et al. 2008, Tartu et al. 2013). Conversely, and for obvious ethical issues, the collection of internal organs can be limited, especially for non-hunted, endangered or declining species. Having information about $\mathrm{Hg}$ levels in different seabird organs is nonetheless essential. It could indeed provide concentrations that could be compared to existing toxicity thresholds. For instance, knowledge of $\mathrm{Hg}$ concentrations in brain or, to a lesser extent, in kidney is limited in seabirds (Espín et al. 2012, Provencher et al. 2014b), contrasting with neurotoxic and nephrotoxic effects of this contaminant (Nicholson \& Osborn 1983, Wolfe et al. 1998, Dietz et al. 2013). Defining such $\mathrm{Hg}$ levels in seabird organs would also allow estimating bird total $\mathrm{Hg}$ body burden and it impacts on bird ecophysiology, reproduction or survival. In that context, we found in both healthy and stranded birds a strong relationship between $\mathrm{Hg}$ concentrations in whole blood and $\mathrm{Hg}$ concentrations in other internal tissues, demonstrating how blood samples can be used to predict $\mathrm{Hg}$ levels in other organs of North Atlantic seabirds. Nevertheless, we also highlight the importance to consider bird state when inferring $\mathrm{Hg}$ contamination of internal tissues from blood $\mathrm{Hg}$ concentrations as bird state significantly affects blood-brain, blood-liver and blood-kidney $\mathrm{Hg}$ concentrations correlations. Moreover, relationships might be different when specifically considering plasma or red blood cells, and further studies focused on these two fractions are needed to provide a complete understanding of the use of blood as predictor of seabird $\mathrm{Hg}$ contamination.

\section{Conclusion}

By analyzing $\mathrm{Hg}$ concentrations in five different tissues of seabirds washed up on shore during a massive mortality event, and belonging to four different species, we provide new insights about the role played by $\mathrm{Hg}$ in seabird winter wrecks. More specifically, stranded 
birds showed the highest $\mathrm{Hg}$ concentrations measured in these species. While liver and brain concentrations were below acute toxicity thresholds, kidney concentrations reached levels close to those of liver, and could be associated with sub-lethal kidney lesions. Although not directly responsible for the high observed mortality, we believe that $\mathrm{Hg}$ has been a major aggravating stress factor for emaciated birds already on the edge. Furthermore,we also demonstrated howHg in blood, which can be non-lethallycollected in seabirds, is related to concentrations in kidney, liver, muscle and brain, andcan therefore be used as a predictor of $\mathrm{Hg}$ contamination in seabird tissues.

\section{Acknowledgments}

We are grateful to J-C. Lemesle, P-A.Farque,G. Martin, LPO France and LPO CharenteMaritime for having coordinated beach surveys and seabird collections during the massive seabird mortality event, and to everyone who helped collecting seabird carcasses on beaches.We thank the wildlife center 'Centre de Sauvegarde du Marais aux Oiseaux' for storing and providing us with carcasses they received during the wreck episode. We are also grateful to M. Brault-Favrouand C.Churlaudfrom the plateforme'Analyses Elémentaires' (University La Rochelle - LIENSs) for their assistance with laboratory work. The Contrat de ProjetEtatRégion (CPER 13) is also acknowledged for funding the AMA. J.F. is supported by grants from the RégionPoitou -Charentes and the European Commission (Marie CurieCareer Integration Grant, Project 631203).

\section{References}


AschnerM, Aschner JL. Mercury neurotoxicity: mechanisms of blood-brain barrier transport. NeurosciBiobehav R1990;14:169-76.

Bond AL, Robertson GJ, Lavers JL, Hobson KA, Ryan PC. Trace element concentrations in harvested auks from Newfoundland: Toxicological risk of a traditional hunt. EcotoxEnviron Safe 2015;115:1-6.

Bulté G, Robinson SA, Forbes MR, Marcogliese DJ. Is there such thing as a parasite free lunch? The direct and indirect consequences of eating invasive prey.EcoHealth 2012;9:6-16.

Bustamante P, Lahaye V, Durnez C, Churlaud C, Caurant F. Total and organic Hg concentrations in cephalopods from the North East Atlantic waters: influence of geographical origin and feeding ecology. Sci Total Environ 2006;368:585-96.

Cipro CVZ, Cherel Y, Miramand P, Caurant F, Méndez-Fernandez P, Bustamante P. Trace elements in the white-chinned-petrel (Procellariaaequinoctialis) from the Kerguelen Islands, Southern Indian Ocean. Polar Biol 2014;37:763-71.

Debacker V, Holsbeek L, Tapia G, Gobert S, Joiris CR, Jauniaux T, et al. Ecotoxicological and pathological studies of common guillemots Uriaaalge beached on the Belgian coast during six successive wintering periods(1989-90 to 1994-95). Dis AquatOrgan 1997;29:159-68.

Debacker V, Jauniaux T, Coignoul F,Bouquegneau, JM. Heavy metals contamination and body condition of wintering guillemots (Uriaaalge) at the Belgian coast from 1993 to 1998. Environ Res 2000;84:310-7.

Debacker V, Rutten A, Jauniaux T, Daemers C, Bouquegneau JM. Combined effects of experimental heavy-metal contamination $\left(\mathrm{Cu}, \mathrm{Zn}\right.$, and $\left.\mathrm{CH}_{3} \mathrm{Hg}\right)$ and starvation on quail's body condition. Biol Trace ElemRes 2001;82:87-107. 
Debacker V, Schiettecatte LS, Jauniaux T, Bouquegneau JM. Influence of age, sex and body condition on zinc, copper, cadmium and metallothioneins in common guillemots (Uriaalge) stranded at the Belgian coast. Mar Environ Res 2001;52:427-44.

Dietz R, Sonne C, Basu N, Braune B, O'Hara T, Letcher RJ, et al. What are the toxicological effects of mercury in Arctic biota? Sci Total Environ 2013;443:775-90.

Erbachet AL. Utilisation de l'échographie pour l'évaluation de lacondition corporelle chez les oiseaux marins. Master report, Université Montpellier II; 2012.

Espín S, Martínez-López E, Gómez-Ramírez P, María-Mojica P, García-Fernández AJ. Razorbills (Alcatorda) as bioindicators of mercury pollution in the southwestern Mediterranean.Mar Pollut Bull 2012;64:2461-70.

Farque PA. Echouage massif d'oiseaux marins durant 1'hiver 2014 sur la façade atlantique. Rapport LPO/MEDDE; 2014.

Fort J, Porter WP, Grémillet D. Thermodynamic modelling predicts energetic bottleneck for seabirds wintering in the northwest Atlantic. JExpBiol 2009;212:2483-90.

Fort J, Robertson GJ, Grémillet D, Traisnel G, Bustamante P. Spatial ecotoxicology: migratory Arctic seabirds are exposed to mercury contamination while overwintering in the northwest Atlantic. EnvironSciTechnol 2014;48:11560-7.

Gaston AJ. Observations on" turr" Hunting in Newfoundland: Age, Body Condition, and Diet of Thick-billed Murres (UriaLomvia), and Proportions of Other Seabirds, Killed Off Newfoundland in Winter. Environment Canada, Canadian Wildlife Service; 1983.

Gaston AJ. Seabirds: a natural history. Yale University Press; 2004.

Gaston AJ, Jones IL. The auks: alcidae. Oxford University Press; 1998. 
Goodale MW, Evers DC, MierzykowskiSE, Bond AL, Burgess NM, Otorowski CI, et al. Marine foraging birds as bioindicators of mercury in the Gulf of Maine. EcoHealth 2008;5:409-25.

Goutte A, Barbraud C, Meillère A, Carravieri A, Bustamante P, Labadie P, et al. Demographic consequences of heavy metals and persistent organic pollutants in a vulnerable long-lived bird, the wandering albatross. P Roy Soc B-BiolSci 2014a;281:20133313.

Goutte A, Bustamante P, Barbraud C, Delord K, Weimerskirch H,Chastel O. Demographic responses to mercury exposure in two closely related Antarctic top predators. Ecology 2014b;95:1075-86.

Greenhouse SW, Geisser S.On methods in the analysis of profile data.Psychometrika $1959 ; 24: 95-112$.

Harris M, Wanless S. The biggest Atlantic Puffin wreck yet. British Birds 2013;106:242-3.

Joiris CR, Tapia G, Holsbeek L. Increase of organochlorines and mercury levels in common guillemots Uriaaalge during winter in the southern North Sea. Mar PollutBull 1997;34:1049-57.

Lindstrom A, Kvist A, Piersma T, Dekinga A, Dietz MW. Avian pectoral muscle size rapidly tracks body mass changes during flight, fasting and fuelling. J ExpBiol 2000;203:913-9.

Lucia M, Bocher P, Cosson RP, Churlaud C, Robin F, Bustamante P. Insight on trace element detoxification in the Black-tailed Godwit (Limosalimosa) through genetic, enzymatic and metallothionein analyses. Sci Total Environ 2012;423:73-83.

Moseley C, Grémillet D, Connan M, Ryan PG, MullersRHE, van der Lingen CD, et al. Foraging ecology and ecophysiology of Cape gannets from colonies in contrasting feeding environments. J Exp Mar BiolEcol2012;422:29-38. 
Nicholson JK, Kendall MD, Osborn D. Cadmium and mercury nephrotoxicity. Nature 1983;304:633-5.

Nicholson JK, Osborn D. Kidney lesions in pelagic seabirds with high tissue levels of cadmium and mercury. J Zool 1983;200:99-118.

Pérez-López M, Cid F, Oropesa AL, Fidalgo LE, LópezBeceiro A, Soler F. Heavy metal and arsenic content in seabirds affected by the Prestige oil spill on the Galician coast (NW Spain). Sci Total Environ 2006;359:209-20.

Piatt JF, Van Pelt TI. Mass-mortality of Guillemots (Uriaaalge) in the Gulf of Alaska in 1993.Mar Pollut Bull 1997;34:656-62.

Provencher JF, Braune BM, Gilchrist HG, Forbes MR, Mallory ML. Trace element concentrations and gastrointestinal parasites of Arctic terns breeding in the Canadian High Arctic. Sci Total Environ 2014b;476:308-16.

Provencher JF, Mallory ML, Braune BM, Forbes MR, Gilchrist HG. Mercury and marine birds in Arctic Canada: effects, current trends, and why we should be paying closer attention. Environ Rev 2014a;22:244-55.

Pyle P. Age determination and molt strategies in North American alcids.Mar Ornithol 2009;37:219-26.

Ribeiro AR, Eira C, Torres J, Mendes P, Miquel J,Soares AM, et al. Toxic element concentrations in the razorbill Alcatorda (Charadriiformes, Alcidae) in Portugal. Arch Environ Con Tox 2009;56:588-95.

Rutkiewicz J, Nam DH, Cooley T, Neumann K, Padilla IB, Route W, et al. Mercury exposure and neurochemical impacts in bald eagles across several Great Lakes states. Ecotoxicology 2011;20:1669-76. 
Sanpera C, Valladares S, Moreno R, Ruiz X, Jover L. Assessing the effects of the Prestige oil spill on the European shag (Phalacrocoraxaristotelis): trace elements and stable isotopes. Sci Total Environ 2008;407:242-9.

Savinov VM, Gabrielsen GW, Savinova TN. Cadmium, zinc, copper, arsenic, selenium and mercury in seabirds from the Barents Sea: levels, inter-specific and geographical differences. Sci Total Environ 2003;306:133-58.

Scheuhammer A, Braune B, Chan HM, Frouin H, Krey A, Letcher R, et al. Recent progress on our understanding of the biological effects of mercury in fish and wildlife in the Canadian Arctic.Sci Total Environ 2015;509-510:91-103.

Tan SW, Meiller JC, Mahaffey KR. The endocrine effects of mercury in humans and wildlife.CritRev Toxicol 2009;39:228-69.

Tartu S, Goutte A, Bustamante P, Angelier F, Moe B, Clément-Chastel C, et al.To breed or not to breed: endocrine response to mercury contamination by an Arctic seabird. Biol Lett 2013;9:20130317.

The Seabird Group. The Seabird Group Newsletter 128; 2015

Wenzel C, Adelung D. The suitability of oiled guillemots (Uriaaalge) as monitoring organisms for geographical comparisons of trace element contaminants. Arch Environ ConTox 1996;31:368-77.

Wolfe MF, Schwarzbach S, \&Sulaiman RA. Effects of mercury on wildlife: a comprehensive review. Environ ToxicolChem 1998;17:146-60.

Zillioux EJ, Porcella DB, Benoit JM. Mercury cycling and effects in freshwater wetland ecosystems.Environ ToxicolChem 1993;12:2245-64. 
1 Table 1. (A) $\mathrm{Hg}$ concentrations (in $\mu \mathrm{g} \cdot \mathrm{g}^{-1}$ of $\mathrm{dw}$ ) and (B) total amount of $\mathrm{Hg}$ (in $\mathrm{mg}$ ) in tissues of wintering seabirds which died during the

2 massive mortality event which occurred along the French coasts in February and March 2014. Values are means \pm SD (n).

\begin{tabular}{lccccc}
\hline \multicolumn{5}{c}{ Hg concentration $\left(\mu g . g^{-1} \mathrm{dw}\right)$} \\
\hline Species & Blood & Liver & Kidney & Muscle & Brain \\
\hline Atlantic puffin & $7.12 \pm 2.58(6)^{\mathrm{a}}$ & $8.64 \pm 2.30(15)^{\mathrm{b}}$ & $6.87 \pm 2.79(15)^{\mathrm{a}}$ & $2.25 \pm 0.57(15)^{\mathrm{c}}$ & $1.35 \pm 0.39(14)^{\mathrm{d}}$ \\
Common guillemot & $6.32 \pm 5.17(8)^{\mathrm{abc}}$ & $5.53 \pm 1.49(13)^{\mathrm{a}}$ & $5.14 \pm 1.84(13)^{\mathrm{a}}$ & $2.08 \pm 0.57(13)^{\mathrm{b}}$ & $1.42 \pm 0.46(13)^{\mathrm{c}}$ \\
Kittiwake & $8.58 \pm 2.82(8)^{\mathrm{a}}$ & $10.77 \pm 4.24(8)^{\mathrm{a}}$ & $8.43 \pm 2.62(8)^{\mathrm{a}}$ & $4.44 \pm 1.66(8)^{\mathrm{b}}$ & $2.47 \pm 0.76(8)^{\mathrm{c}}$ \\
Razorbill & $9.38 \pm 4.12(7)^{\mathrm{a}}$ & $10.13 \pm 4.71(7)^{\mathrm{a}}$ & $6.48 \pm 2.14(7)^{\mathrm{a}}$ & $3.99 \pm 1.56(7)^{\mathrm{b}}$ & $2.22 \pm 0.99(7)^{\mathrm{c}}$ \\
& & & & & \\
Razorbill (2006) & $4.46 \pm 2.10(20)$ & $4.25 \pm 1.68(20)$ & $3.77 \pm 1.50(20)$ & $2.04 \pm 0.88(21)$ & $2.05 \pm 0.84(21)$
\end{tabular}

Total amount of $\mathrm{Hg}(\mathrm{mg})$

\begin{tabular}{|c|c|c|c|c|c|}
\hline Species & Blood & Liver & Kidney & Muscle & Brain \\
\hline Atlantic puffin & -- & $14.91 \pm 4.80(15)$ & $5.79 \pm 2.62(15)$ & -- & $0.99 \pm 0.32(13)$ \\
\hline Common guillemot & -- & $19.50 \pm 5.00(13)$ & $6.83 \pm 2.72(13)$ & -- & $1.17 \pm 0.44(13)$ \\
\hline Kittiwake & -- & $24.71 \pm 12.57(8)$ & $5.84 \pm 2.36(8)$ & -- & $1.72 \pm 0.56(8)$ \\
\hline Razorbill & -- & $24.19 \pm 14.95(7)$ & $7.74 \pm 3.45(7)$ & -- & $1.61 \pm 0.80(7)$ \\
\hline Razorbill (2006) & -- & $47.53 \pm 20.72(20)$ & $10.75 \pm 4.30(20)$ & -- & $1.70 \pm 0.71(20)$ \\
\hline
\end{tabular}

4 For each species/year, different letters denote significant statistical differences. 
5 Table 2. Relationships between $\mathrm{Hg}$ concentrations in blood and $\mathrm{Hg}$ concentration measured in other tissues, in both healthy seabirds (razorbills

6 collected in 2006) and emaciated seabirds (stranded Atlantic puffins, common guillemots, razorbills and kittiwakes collected during the massive

7 winter mortality event in 2014).

8

\begin{tabular}{|c|c|c|c|c|c|}
\hline Healthybirds & $\mathrm{R}^{2}$ & $\mathrm{p}$-value & Strandedbirds & $\mathrm{R}^{2}$ & $\mathrm{p}$-value \\
\hline $\log [\mathrm{Hg}]_{\text {Liver }}=0.81 * \log [\mathrm{Hg}]_{\text {Blood }}+0.11$ & 0.92 & $<0.001$ & $\log [\mathrm{Hg}]_{\text {Liver }}=0.69 * \log [\mathrm{Hg}]_{\text {Blood }}+0.32$ & 0.55 & $<0.001$ \\
\hline $\log [\mathrm{Hg}]_{\text {Muscle }}=0.83 * \log [\mathrm{Hg}]_{\text {Blood }}-0.22$ & 0.89 & $<0.001$ & $\log [\mathrm{Hg}]_{\text {Muscle }}=0.74 * \log [\mathrm{Hg}]_{\text {Blood }}-0.15$ & 0.60 & $<0.001$ \\
\hline $\log [\mathrm{Hg}]_{\text {Kidney }}=0.82 * \log [\mathrm{Hg}]_{\text {Kidney }}+0.05$ & 0.91 & $<0.001$ & $\log [\mathrm{Hg}]_{\text {Kidney }}=0.58 * \log [\mathrm{Hg}]_{\text {Kidney }}+0.32$ & 0.48 & $<0.001$ \\
\hline $\log [\mathrm{Hg}]_{\text {Brain }}=0.89 * \log [\mathrm{Hg}]_{\text {Brain }}-0.26$ & 0.95 & $<0.001$ & Log $[\mathrm{Hg}]_{\text {Brain }}=0.70 * \log [\mathrm{Hg}]_{\text {Brain }}-0.35$ & 0.62 & $<0.001$ \\
\hline
\end{tabular}


9
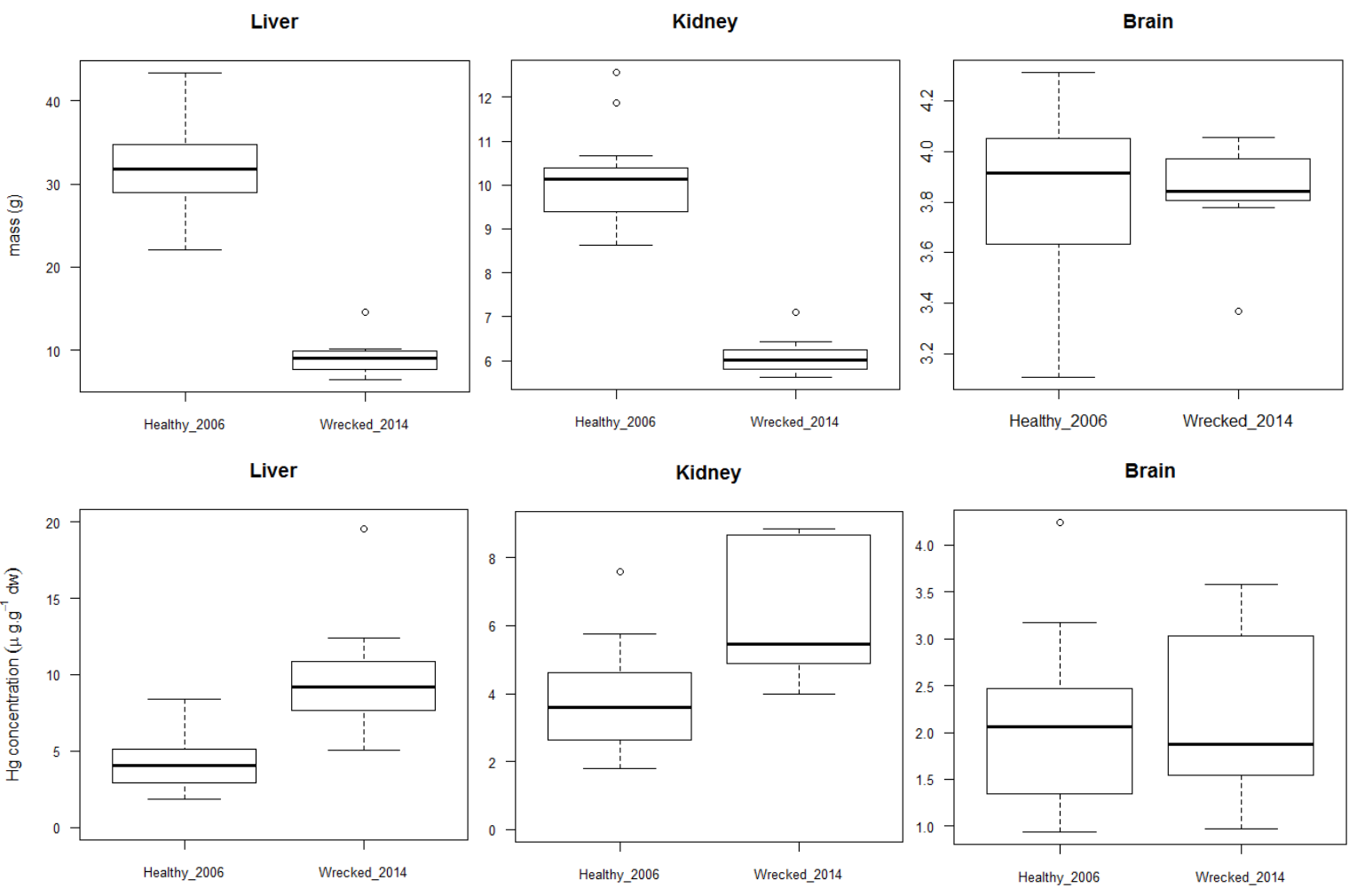

10
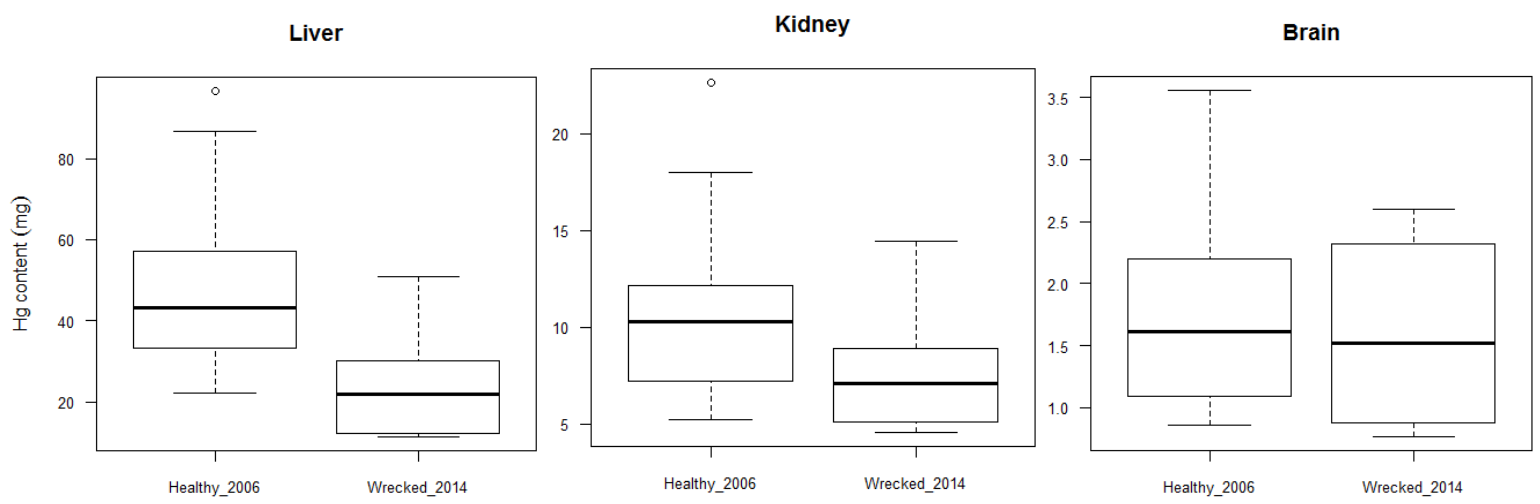

11

12

13 Figure 1. Differences in wet mass (g; upper panel), $\mathrm{Hg}$ concentrations ( $\mu \mathrm{g} . \mathrm{g}^{-1} \mathrm{dw}$; middle panel) and total $\mathrm{Hg}$ content (mg; lower panel) in liver, kidney and brain between razorbill collected in 2006 (healthy condition) and razorbills collected during the massive mortality event in 2014 (see Methods for details). 

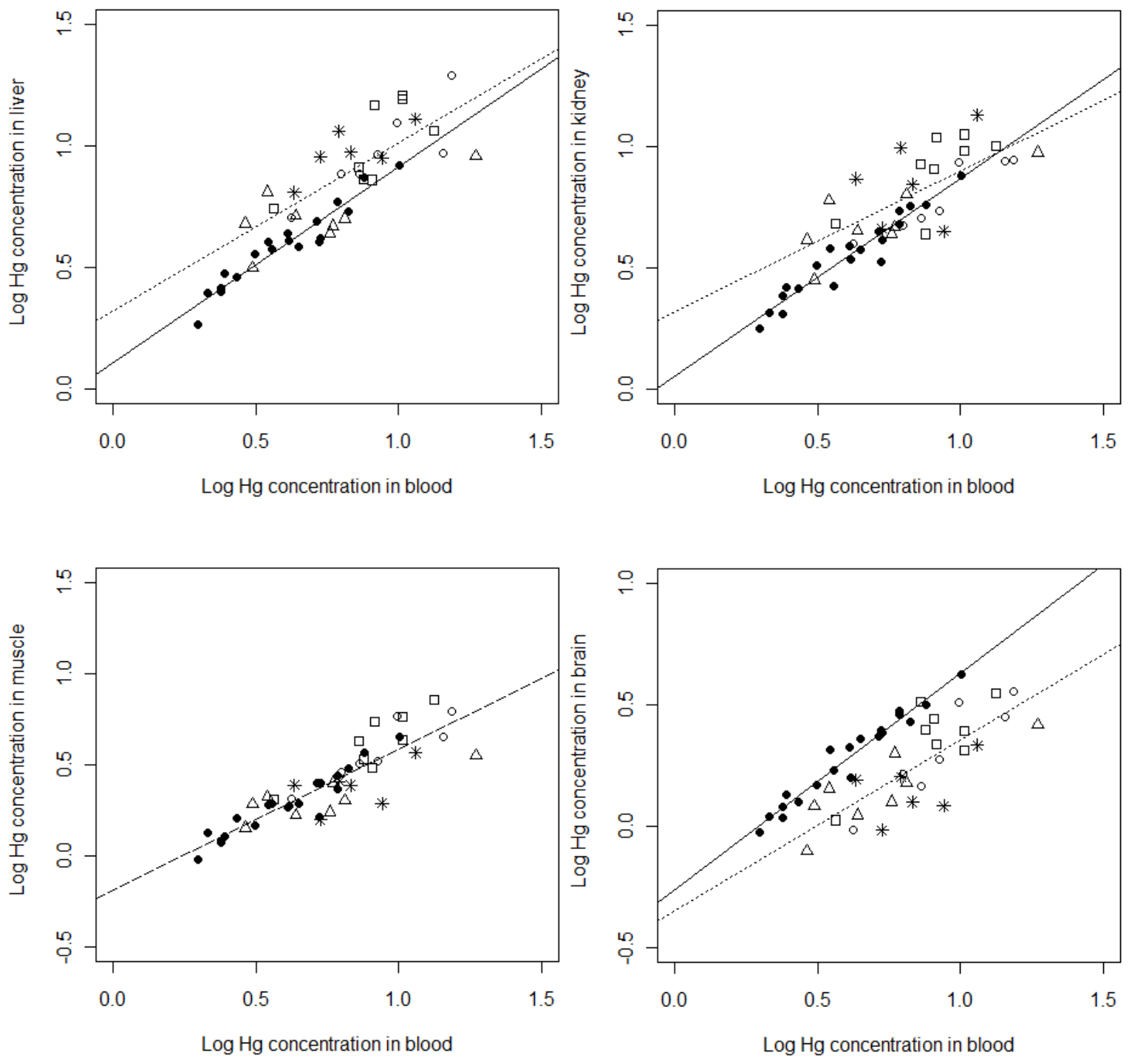

19

Figure 2. Relationship between $\mathrm{Hg}$ concentrations (in $\mu \mathrm{g} \cdot \mathrm{g}^{-1} \mathrm{dw}$ ) measured in blood and in (A) liver, (B) kidney, (C) muscle and (D) brain in Arctic seabirds. Open-symbols: stars, squares, triangles and circles are for wrecked Atlantic puffins (Fraterculaarctica), black-legged kittiwakes (Rissatridactyla), common guillemots (Uriaaalge) and razorbills (Alcatorda), respectively. Black-filled circles represent razorbills in healthy conditions found in 2006. Dotted regression lines show relationships for stranded birds (2014) and include all species. Solid regression lines show relationships for healthy birds (razorbills 2006). Dashed regression line show relationship for both healthy and stranded birds and include all data when bird state had no effect on the relationship (see methods for details). 